\title{
Methodological function of the "genomic information" notion for human genome interdisciplinary researches
}

\author{
Lyudmila N. Berg \\ Ural State Law University, Ekaterinburg, Russian Federation \\ \mila-berg@mail.ru
}

\begin{abstract}
The author is convinced that a notion 'genomic information' is widespread in sciences thus justifies that a genomic information is already a general scientific notion. The author differentiates internal and external factors that have a great impact on the notion of 'genomic information'. Internal factors are digitalization of sciences, interdisciplinary research, and a new type of rationality in science. External factors are modern economy that is based on scientific and technical progress. The article refers to the theory of notions' ranges that was substantiated by A.M. Vasil'ev. It creates a new notions' range concerning the notion of 'genomic information'. It is crucial to understand that this notion is investigated in the aspect of legal information. In the author's opinion, notions' range concerning the 'genomic information' notion forms the basis for a fresh interdisciplinary law-and-genome theory which will be developing consequently. The author asserts that it is necessary to use general scientific approaches for law-and-genome information's research. In this sense systematic and informational approaches are the most significant for interdisciplinary law-and-genome theory ones.

Key words: genomic information, legal information, law-and-genome information, general scientific notion, notions' range, use general scientific approach, interdisciplinary law-and-genome theory, systematic approach, informational approach

Conflict of interest. The author declares no conflict of interest.

Funding information. The article has been prepared within the framework of the assignment of the Ministry of Education and Science of the Russian Federation, project 26.12267.2018/12.1.
\end{abstract}

Article received 14th May 2021

Article accepted 15th October 2021

\section{For citation:}

Berg, L.N. (2021) Methodological function of the "genomic information" notion for human genome interdisciplinary researches. RUDN Journal of Law. 25 (4), 888-900. DOI: 10.22363/2313-2337-2021-25-4-888-900 


\title{
Методологическое значение понятия «геномная информация» в междисциплинарных исследованиях генома человека
}

\author{
Л.Н. Берг $\mathbb{D}$ \\ Уральский государственный юридический университет, \\ Екатеринбург, Российская Федераџия \\ $\triangle$ mila-berg@mail.ru
}

\begin{abstract}
Аннотация. Обосновывается довод о том, что понятие «геномная информация» используется во многих отраслях научного знания, а потому может претендовать на статус общенаучного понятия. При этом автор отмечает, что на формирование понятия «геномная информация» влияют как внутренние, или интернаучные факторы (в частности, цифровая трансформация и интеграция науки, развитие междисциплинарных исследований, ориентация на новый вид научной рациональности), так и внешние факторы, или социальные основания (экономика производства на основе новейших технологий и научных достижений). С позиции теории понятийных рядов, разработанной А.М. Васильевым, автор предлагает структурный понятийный ряд геномной информации. По мнению автора, данный понятийный ряд служит основой для построения новой междисциплинарной правогеномной концепции, которая будет развиваться в несколько последовательных этапов. Автор также указывает на необходимость использования общенаучных подходов к изучению правогеномной информации, указывая на особую значимость информационного и системного подходов.
\end{abstract}

Ключевые слова: геномная информация, правовая информация, правогеномная информация, общенаучное понятие, понятийный ряд, общенаучный подход, междисциплинарная правогеномная концепция, системный подход, информационный подход

Конфликт интересов. Автор заявляет об отсутствии конфликта интересов.

Информация о финансировании. Исследование выполнено в рамках государственного задания Минобрнауки РФ, шифр проекта: 26.12267.2018/12.1.

Дата поступления в редакиию: 14 мая 2021 г.

Дата принятия к печати: 15 октября 2021 г.

\section{Для цитирования:}

Берг Л.Н. Методологическое значение понятия «геномная информация» в междисциплинарных исследованиях генома человека // RUDN Journal of Law. 2021. T. 25. № 4. С. 888 900. DOI: $10.22363 / 2313-2337-2021-25-4-888-900$

\section{Introduction}

First of all, it is necessary to define the place of the concept of «genomic information» in the thesaurus of scientific knowledge. It is worth noting that this concept is applied in most branches of modern scientific knowledge: natural sciences (biology, medicine, genetics, genomics, where the concept of 'genome' originates), social sciences and humanities (law, sociology, whose representatives understand phenomena in terms of their significance for society and human beings), technical 
sciences (for example, computer science, where ways of storing and using genomic information are developed). The Great Russian Encyclopedia states that the key aim of structural genomics is to research the content and organization of genomic information - the sequence of nucleotides of all DNA molecules of a cell (nuclear, mitochondrial and chloroplast) (Miheev, 2016).

Within the technical sciences "genomic information» is closely related to such concept as 'Big data'. The term 'Big data' is called "cultural, technological and scientific phenomenon that maximizes computational power and algorithmic accuracy for the collection, analysis, binding and comparison of large data sets" (Ajunwa, 2014). The analysis of 'genomic information' is most effectively carried out with the help of these technologies in testing, scientific research or providing medical care (Ajunwa, 2014). But at the same time there is the issue of human genomic and genetic data protection from information leakage when using data processing technologies 'Big data'. Special stand-alone software tools are being developed to improve the defense of genomic information (Fredrich, Schmöhl \& Junge, et al., 2019).

As for social sciences and humanities, and primarily law, the term 'genomic information' is enshrined in the Federal Law No. 242-FL of 03.12.2008 On state genomic registration in the Russian Federation. According to Article 1, paragraph 3 of the Federal Law, genomic information is defined as "personal data, including coded information about certain fragments of deoxyribonucleic acid of an individual or an unidentified corpse that do not characterize their physiological characteristics"1.

By its characteristics and logical-methodological functions, the term differs significantly from the philosophical and private scientific types of scientific concepts, occupying an intermediate position between them as a general scientific one. Indeed, the concept of 'genomic information' for objective reasons cannot be at present implemented for the solution of basic philosophical problems, and therefore it is incorrect to classify it as a category of philosophy. Since the concept goes beyond the individual private sciences and is the basis for a special scientific approach to cognition of the subject of reality, these two characteristics make it fundamentally different from the categories of private sciences.

\section{Genomic Information as a General Scientific Concept}

It should be noted that contradiction in differentiation between the attributes of philosophical and private scientific concepts is eliminated by the new characteristic of general science, which is a syncretic alloy of synthesis of properties of philosophical and private scientific categories; as such, it is inherently contradictory and is therefore a driving force for further development of general scientific categories.

\footnotetext{
${ }^{1}$ Federal Law No. 242-FL of 03.12.2008 On state genomic registration in the Russian Federation // Collection of legislation of the Russian Federation. 2008. No. 49, Article 5740.
} 
At the same time, it is necessary to distinguish an internal contradiction in the establishment and development of the 'genomic information' concept as a general scientific concept. For example, quite naturally there is a conflict between the emerging general scientific concept of 'genomic information' and traditional, already established components of the conceptual arsenal of science, stable conceptual systems. Since both well-established and emerging concepts are used simultaneously in research. Therefore, they are often linked, and the scope of concepts may overlap. It is possible to observe certain contradictions between the new emerging concept of 'genetic information' and category of 'information' claiming the status of philosophical category.

Continuing the basic analysis of this general scientific concept, it is essential to raise the question of the causal connection between the integration of the concept of 'genomic information' into a single, holistic fusion with related concepts, for example, «genetic information» and to isolate them as general scientific concepts. Since there is a reason to believe that the driving forces behind the development of these concepts in general science are the digital transformation and integration of science, the development of interdisciplinary research focused on the solution of complex general scientific problems is orientation towards a new type of scientific rationality. The presented complex of factors acts jointly, syncretically, and systemically and represents predictive modern stage of development trends in science.

In addition to the influence of interscientific factors, the concept is strongly influenced by social sources associated with the economics of production based on the latest technologies and scientific advances. Strengthening the role of economic constituents is linked to the target customers in the form of government and large corporations. For example, leading technology companies are currently attempting to identify genetic and genomic resistance factors to coronavirus and are developing relevant databases. The research is carried out in the following way: grouping the data of the genetic analyses of the respondents and filling out anonymous questionnaires concerning the respiratory diseases, including coronavirus. If the answer to coronavirus is positive, a number of clarifying questions are proposed; they give an idea about the disease. The results of such genetic studies, if successful, would provide scientifically sound criteria for identifying groups of patients, including better identification of risk groups. This would contribute to correct clinical recommendations, selection of personalized treatment scheme, development of target drugs, etc. The quality of the research data would depend on how well the questionnaire is designed. To make any predictions, it will be necessary to superimpose survey data on the respondents' genomic data. It would be possible to identify DNA sites that predetermine the course of the disease by analyzing large amounts of clinical, background and genomic data applying bioinformatics and statistical methods ${ }^{2}$.

\footnotetext{
${ }^{2}$ Russian company began searching for genetic "immunity" to coronavirus. Available at: $\quad$ https://www.vedomosti.ru/business/articles/2020/04/08/827435-rossiiskaya-kompaniya-nachala-poiskgeneticheskogo-immuniteta-k-koronavirusu [Accessed 8 April 2021].
} 
Thus, we confirm the intermediate conclusion that internal and external factors are the driving force for the development of the 'genomic information' concept that claim the status of general science.

\section{Characterization of genomic information as legal information}

It is particularly important to stress that the meaning and role of a general scientific concept can be presented in conjunction with similar means, for example, in the conceptual set. The rules and basic principles of the conceptual set construction were laid down by A.M. Vasil'ev. The conceptual set construction is possible on structural, historical, functional and other grounds. "The legal categories and concepts that express the elements of legal matter characterizing its internal organization are diverse, varied in degree of generalization and logical level. Therefore, there is the need for their logical grouping in the way allowing to express the internal organization of the legal form" (Vasil'ev, 2021). We can build the conceptual set regarding 'genomic information' and recognize it as legal information. In turn, the concept of 'legal information' includes the message and other data contained in legal acts, normativetechnical, reference and scientific materials as well as information of a legal nature created and transmitted by subjects in the course of their interaction, resulting in streamlining their activities (Berg, 2021).

Most often, genomic information is defined as personal data that includes information about certain DNA fragments of an individual or an unidentified corpse. This definition, enshrined in the Federal Law on State Genomic Registration, is specific and narrowly focused on identifying, detecting, preventing, and raising awareness of crime.

However, genomic information may also be obtained in other cases, such as medical services, research and genetic tests (Boltanova, Trychenkov \& Pshenichnikova, 2019).

Among other things, genomic information is not properly identified with personal data. In accordance with Article 3, paragraph 1 of Federal Law No. 152-FL of 27 July 2006 "On personal data", personal data is any information relating directly or indirectly to a specific or identifiable natural person ${ }^{3}$ No doubt, genomic information contains unique features of an identifiable subject. But besides the characteristic of individuality, this information has the property of «hereditary» (Boltanova, Trychenkov \& Pshenichnikova, 2019) and therefore contains information about several generations of relatives of the identifiable subject.

Thus, unfolding conceptual set relative to 'genomic information', we can single out the concepts of the first stage specification - 'types of genomic information'. The basis for classification is the subject to be identified, or more precisely the possibility of its identification. Thus, we will extract 'personalized genomic information' and 'non personalized genomic information'.

\footnotetext{
${ }^{3}$ Federal Law No. 152-FL of 27 July 2006 "On personal data" // Collection of legislation of the Russian Federation. 2006. No. 31 (1), Article 3451.
} 
According to Federal Law No. 149-FL of 27 July 2006, On information, information technology and information protection ${ }^{4}$ the legislator establishes categories of access to information. Confidential information is a subspecies of information category «restricted information». The President of the Russian Federation Decree No. 188 dated 6 March $1997^{5}$ establishes the confidential information list. These include personal data, official secrets, professional secrets, trade secrets and some others. Without question, access to genomic information should be restricted. Genomic information is restricted confidential information.

In the light of the foregoing, we proceed to the second stage of specification, regime of access to 'genomic information'. Depending on its type and scope, it is defined as a regime for access to personal data, official, professional or trade secrets.

The third and fourth stages of specification of the structural conceptual set may be the following concepts - 'biological sample of genomic information', which may be blood, saliva, blood plasma, epithelium cells, etc., and 'method of obtaining genomic information' (namely, medical, or scientific research, medical examination, testing, screening, etc.). Special rules must be established for each type of specimen and the manner of its obtaining, which must be in line with the legislation of the Russian Federation and international law.

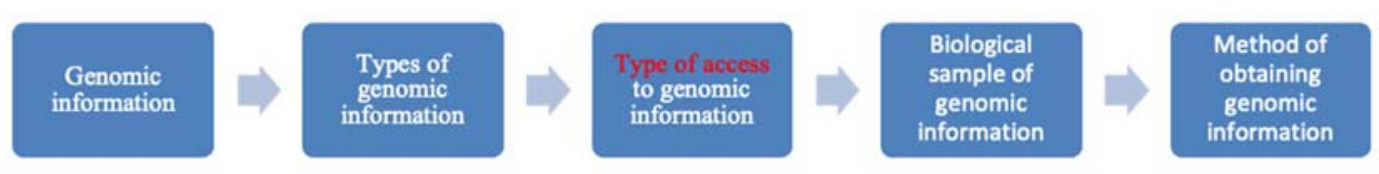

Fig. 1. The concept set defining "genomic information" in the aspect of legal information

Material presented in Figure 1 allows to conclude that the proposed concept set is not yet a definite concept. Nevertheless, it represents a number of concepts relating to legal means of legal action and, accordingly, allows to identify certain areas for their further development. We emphasize that the expedient implementation of the general scientific concept of 'genomic information' will considerably increase the standard of theoretical developments in legal science.

Thus, while in the traditional branches of legal sciences the pool of research tools is clear, in the new branches of legal knowledge that are emerging from intensive genomic law research, the role of new learning tools becomes particularly important. Here, it is very important to analyze the significance of science-based tools, to which

\footnotetext{
${ }^{4}$ Federal Law No. 149-FL of 27 July 2006, On information, information technology and information protection // Collection of legislation of the Russian Federation. 2006. No. 31 (1), Article 3448.

${ }^{5}$ President of the Russian Federation Decree No. 188 dated 6 March 1997 On approval of the list of confidential information // Collection of legislation of the Russian Federation. No. 10, Article 1127.
} 
general scientific concepts clearly belong, irrespective of whether they are established or still emerging.

In this connection, appearance of new objects and the resulting formation of subjects of legal science, is based on a progressive understanding of the unknown properties of the phenomenon. The emergence of new concepts should be an extension of this fact, as they may form the basis for separate concepts, even theories. Thus, the general scientific concept of «genomic information» naturally realizes this role in lawgenomic research.

We believe that the 'genomic information' represented by a conceptual set, which is divided into species terms (types of genomic information, types of access to genomic information, biological sample of genomic information, method of obtaining genomic information) may lay foundation for constructing a new interdisciplinary legal-genome theory, since the theory of any science is linked in the gnoseological process to general scientific concepts and conceptual sets of reciprocal dependence. For example, the very appearance of the general scientific concept of 'genomic information' in the thesaurus of legal science is convincing evidence of legal knowledge development. Accordingly, emergence of 'genomic information' as a general scientific concept is the statement of intensification of legal theory.

Thus, we assert that general scientific concepts, including 'genomic information', are jointly associated with general scientific methods and approaches and become methodological tools of legal theory in the process of special legalgenome theory formation. It is only natural that there will be qualitatively different levels of interpretation of the concept in the first stage of legal-genome concept development. In the first stages 'genomic information' will have exclusively practical interpretation. Then, differentiating themselves from certain empiricism, such concepts gradually begin fulfilling a methodological function, providing a basis for general scientific methods and approaches to exploring objects, in our case, social relations, connected with circulation of genomic information. Only at theoretical stage, when the general scientific concept of 'genomic information' is differentiated from the possible practical component it becomes the methodological basis for a new special legal-genome theory formation. That is, it will begin to acquire qualitative interpretation of gnoseology and methodology of the legal science. In essence, general scientific concept of 'genomic information' and corresponding conceptual set, are projected by the researcher to the studied object (public relations connected with genomic information turnover) and provide a conceptual basis for applying general scientific methods and approaches.

The concept set can be compared to a system of certain algorithms that express sufficiently one-dimensional concepts in meaning. Only after the conceptual set stabilizes and we can record the logical certainty, the constituents of the conceptual set can be used without intermediate interpretation as certain epistemological means. Such is the basis for genome-based theory. 
It is evident that the two levels of interpretation (empirical and theoretical) of genomic information under study are presented dialectically and are often used syncretically in scientific knowledge. Together they allow to form a certain theoretical subject of research.

For example, 'genomic information' can be sufficiently well interpreted initially through understanding what information is, what its structure is, what kinds of information interactions exist. In our case, we are talking "....about informational interactions operating within the range from the molecular-genetic level to the level of social communities..." (Zholkov, 2017). It is not surprising that research interest in information as a value takes on special importance in biology, because according to biophysicist A.S. Presman, "such quality of information as value arises only in living systems" (Presman, 1997:93). For biological systems, it is not the quantity but the quality of information that is important: "...natural selection — one of the basic factors of evolution - is based on increasing the value of genomic information..." (Lysak, 2015:19).

The unique role of the concept of 'genomic information' in the process of forming the basis of the legal-genome concept can be defined because it contributes to the discovery of features and relationships connected with genomic research.

\section{General scientific approaches in the formation of interdisciplinary legal-genome theory}

Looking at general scientific approaches in the framework of theorizing of legal-genome concept fundamentals, we should note the particular importance of the system approach, which application in private sciences demonstrates significant scientific breakthroughs. For example, the system approach allows to "...explore the variability of individual features of organisms at the level of the entire genome and markers in conjunction with the research of variability of individual biochemical, physiological and morphological features, expression of genes and habitats..." (Krutovskiy, 2006). Such data have made it possible to identify human genes and alleles that are responsible for hereditary diseases, predisposition to oncological diseases and mental disorders with complex etiology, sensitivity to medicines, etc. Also, in tree species, genomic analysis has found links between allele genetic variability and variability of important adaptive and breeding phenotypic traits, such as growth rate, wood quality, resistance to disease, freezing, drought, etc. (Eckert, Bower \& Wegrzyn, et al., 2009).

One cannot fail to mention the importance of the informational approach, which has been implemented in different fields of science, in particular, in the process of forming the theory of genomic breeding (Villar-Hernánde, Pérez-Elizalde, Crossa, Pérez-Rodríguez, Toledo \& Burgueño, 2018), investigating the means of transmitting information between the structures of animal DNA, its exterior and practical qualities. Further evidence of the value of information approach can be obtained by looking at 
the legal reality. It is impossible to imagine a modern legal system without creating, transmitting, exchanging and flowing of legal information. In turn, the full cycle of legal development - from legal thinking to law enforcement (Tihomirov, 2008) implies consistent perception, creation, change and transmission of legal information. The permanent and diverse movement of legal information implies not only the different forms of the flow of information referred to above, but also its reflection in the legal consciousness of the individual and its subsequent implementation in behavior (Kudryavcev, 1981).

At the same time, there is the need to focus on the fact that the information approach plays an important role in the development problems analysis when "information feedback, self-regulation and control processes arise on the basis of primitive functional relationships of inorganic systems" (Meluhin, 1966:259).

General scientific concepts and approaches are increasingly being applied in the analysis of direction of development issue. Most scholars are committed to thinking of development from the bottom up, from simple to complex, clearly denoting this as evolution criteria (quantitative and qualitative forward movement). For example, disappearance or initial lack of adaptive value does not lead to the loss of the relevant body of information. As a result, the rate of accumulation of information exceeds the rate of evolution, i.e., the rate of accumulation of adaptive information. This pattern appears to be common to all forms and all levels of the evolutionary process, from molecular-genetic (genome structure) to sociocultural and technological (Cheshko \& Glazko, 2009). In biological evolution, this manifests itself both in redundant DNA accumulation (Cheshko \& Glazko, 2003). in the genome that has no coding function and in the gradual accumulation of mutations that are not adaptive in populations of organisms (the so-called non-Darwinian evolution) (Kimura, 1983).

This leads to the idea that there is an interaction between biological, socioeconomic and technological evolution. Let us take for example technological innovation that governs the way of life and, in one form or another, influenced the course of biological processes, destabilizing the space of biological evolution, and thus the resulting vector of socio-economic evolution (Armand, Luri \& Zhernihin, et al., 1999:208).

The basic statement that the law is determined by economy does not now raise any questions. This is also confirmed by the fact that researchers respectfully refer to the theory of economic evolutionary cycles by N. Kondratiev (Kondrat'ev, 1989), which are synchronized with changes in technological patterns. The emergence of new patterns in economy inevitably leads to the emergence of new branches and institutions in law. Moreover, the legal system itself is evolving and acquiring new internal mechanisms for its dynamics. For example, new branches and institutions of law in the field of information, new types of sources of law (doctrines, programs), new channels for transmitting legal information (Internet, social networks, crypto messengers, etc. (Berg, 2021:263) are emerging. Following the economic sphere, the 
legal sphere is also subject to cycles of evolutionary development, including a phase of recovery and a phase of decline. The phase of rise precedes the phase of decline, i.e., the phase of asocial destruction, which, in the terminology of J. Schumpeter, represents "creative destruction" (Schumpeter, 1995). In the legal sphere, this is reflected in higher crime rates, inflation of normative legal acts, emergence of legal nihilism in different strata of society, etc. Then, after several years of decline, the formation of legal system with new qualities and characteristics goes on (Cheshko \& Glazko, 2009:207).

Let us sum up the intermediate result that general scientific approaches (information, system, etc.) and general scientific concepts, in our case 'genomic information' give the opportunity to discover new aspects about the boundaries of development, including legal development. The general trend in all three forms (technological, sociocultural and biological) of evolutionary processes with human's participation is accompanied by higher level of organization, adjustment and adaptability. 'Genomic information' as a kind of legal information can guide the actions of subjects, influence their activities. Such information, which is both individual and legal in nature, can have a significant legal impact on subjects of law in various spheres of public relations, such as health care, insurance, employment and others.

In fact, improper disclosure of information obtained from the human genome may lead to genetic discrimination. The National Institute of Health of the United States defines genetic discrimination as "special attitude of an employer or insurance company to a person, due to the fact that he/she has a gene mutation that causes or increases the risk of hereditary disease (disorder)" (Bogdanova, 2019).

For example, a woman was deprived of insurance after the insurance company submitted medical documents for a preventive operation, because "she had a mutation of the BRCA1 gene associated with the increased risk of breast cancer" (Bogdanova, 2019).

Such situations may also impede employment or career progression, mortgage lending in cases of predisposition to Alzheimer's disease or other serious illnesses.

Thus, genomic information can have positive or negative legal effects in different areas of human activity. Such an impact can have very serious consequences in the form of discrimination, and/or abuse of "genomic information. Accordingly, both the special legal status of such information and the special regime for its legal protection are necessary.

\section{Conclusion}

In sum, the methodological meaning of "genomic information" in interdisciplinary studies of the human genome is mediated by applying different general scientific approaches, especially the information and systemic ones. The noted approaches and the concept of "genomic information" may become the basis for emerging new breakthrough ideas and concepts concerning even relatively 
well-studied objects in various fields of scientific knowledge. "Genomic information" expressed by a conceptual set (types of genomic information, type of access to genomic information, biological sample of genomic information, method of obtaining genomic information) can serve as the basis for building a new interdisciplinary legal-genomic concept, since theorization of any science is linked in the gnoseological process with general scientific concepts and conceptual sets of reciprocal dependence, and will also open up new aspects of legal development.

\section{References / Список литературы}

Ajunwa, I. (2014) Genetic testing meets Big data: Tort and Contract Law issues. Ohio, State Law Journal. 75 (6), 1233.

Armand, A.D., Luri, D.I. \& Zhernihin, V.V. et al. (1999) Anatomy of crises. Moscow, Nauka Publ. (in Russian).

Анатомия кризисов / Арманд А.Д., Люри Д.И., Жерихин В.В. и др. М.: Наука, 1999. $238 \mathrm{c}$.

Berg, L.N. (2021) Theory of legal affecting. Moscow, Statut Publ. (in Russian).

Берг Л.Н. Теория правового воздействия: монография. М.: Статут, 2021. 309 c.

Bogdanova, E.E. (2019) Legal risks of genetic revolution: genetic information and discrimination. Lex russica. 6 (151), 18-29. (in Russian).

Богданова Е.Е. Правовые проблемы и риски генетической революции: генетическая информация и дискриминация // Lex russica (Русский закон). 2019. № 6 (151). С. 18-29.

Boltanova, E.S., Trychenkov, N.A. \& Pshenichnikova, K.U. (2019) Genomic information as a type of information within a legal system of the Russian Federation. Issues of Constitutional, Municipal, Administrative and Financial Law. 4 (87), 20-25. (in Russian).

Болтанова Е. С., Трынченков Н. А., Пшеничникова К. Ю. Место геномной информации среди существующих в законодательстве Российской Федерации видов информации // Вопросы конституционного, муниципального, административного и финансового права. 2019. № 4 (87). С. $20-25$.

Cheshko, V.F. \& Glazko, V. I. (2009) High Hume (Bio-power and Bio-policy in Society of Risk). Moscow, Russian State Agrarian University - Moscow Timiryazev. Publ. (in Russian).

Чешко В.Ф., Глазко В.И. High Нume (биовласть и биополитика в обществе риска). Учебное пособие. М.: РГАУ МСХА им. К.А.Тимирязева, 2009. 319 с.

Eckert, A. J., Bower, A. D. \& Wegrzyn, J. L. et al. (2009) Association genetics of coastal Douglasfir (Pseudotsuga menziesii var. menziesii, Pinaceae). I. Cold-hardiness related traits. Genetics. 182 (4), 1289-1302.

Fredrich, B., Schmöhl, M., Junge, O., Gundlach, S., Ellinghaus, D. \& Pfeufer, A., et al. (2019) VarWatch - A stand-alone software tool for variant matching. PLOS ONE. 14 (4), e0215618. https://doi.org/10.1371/journal.pone.0215618

Glazko, V.N. \& Glazko, G.V. (2003) Introduction to genetic. Kiev, KVITs Publ. Pp. 224-226. (in Russian).

Глазко В.Н., Глазко Г.В. Введение в генетику: биоинформатика, ДНК-технология, генная терапия, ДНК-экология, протеомика, метаболика. Киев: КВІЦ, 2003. С. 224-226.

Kimura, M. (1983) The Neutral Theory of Molecular Evolution. Cambridge: Cambridge University Press. https://doi.org/10.1017/CBO9780511623486

Kondrat'ev, N.D. (1989) Big cycles of economic conditions: report. Issues of economic dynamic. Moscow, Ekonomika Publ. Pp. 172-226. (in Russian). 
Кондратьев Н.Д. Большие циклы экономической конъюнктуры: доклад // Проблемы экономической динамики. М.: Экономика, 1989. С. 172-226.

Krutovskiy, K.V. (2006) From population genetics to population genomics of forest trees: integrated population genomics approach. Genetic. 42 (10), 1304-1318. (in Russian).

Крутовский $K . B$. От популяционной генетики к популяционной геномике лесных древесных видов: интегрированный популяционно-геномный подход // Генетика. 2006. T. 42. № 10. С. 1304-1318.

Kudryavcev, U.V. (1981) Legal rule as social information. Moscow, Yuridicheskaya lititeratura Publ. (in Russian).

Кудрявиев Ю.В. Норма права как социальная информация. М.: Юрид. лит., 1981. 144 с.

Lysak, I.V. (2015) Information as a general scientific and philosophical concept basic approaches to its definition. Philosophical problems of information technology and cyberspace. 2 (10), 9-26. (in Russian).

Лысак И.В. Информация как общенаучное и философское понятие: основные подходы к определению // Философские проблемы информационных технологий и киберпространства. 2015. № 2 (10). C. 9-26.

Meluhin, S.T. (1966) Substance in unity, infinity and development. Moscow, Mysl' Publ. (in Russian).

Мелюхин С.T. Материя в ее единстве, бесконечности и развитии. М.: Мысль, 1966. 384 с.

Miheev, V.S. (2016) Genomic Information. The Great Russian Encyclopedia. V. 6. Moscow. Available at: https://bigenc.ru/biology/text/2350490 [Accessed 15th February 2021]. (in Russian).

Михеев В.С. Генетическая информация // Большая российская энциклопедия. Т. 6. М., 2006. 556 с. Режим доступа: https://bigenc.ru/biology/text/2350490 (дата обращения: 21.09.2021).

Presman, A.S. (1997) Organization of the biosphere and its cosmic connection. Moscow, Geo-Sinteg Publ. (in Russian).

Пресман А.С. Организация биосферы и ее космические связи. М.: Гео-Синтег, 1997. $239 \mathrm{c}$.

Schumpeter, I.A. (1995) Capitalism, Socialism and Democracy. Translated from English. Autonomov V.S. (ed.). Moscow, Ekonomika Publ. (in Russain).

Шумпетер Й.А. Капитализм, Социализм и Демократия / пер. с англ.; предисл. и общ. ред. В.С. Автономова. М.: Экономика, 1995. 540 с.

Tihomirov, U.A. (2008) Cycles of legal development. Journal of Russian Law. (10), 15-22. (in Russian).

Тихомиров Ю.А. Циклы правового развития // Журнал Российского права. 2008. № 10. C. $15-22$.

Vasil'ev, A.M. (2021) Legal notions: methodological aspects of theory of law categories' system developing. Moscow, Norma Publ., INFRA-M Publ. (in Russian).

Васильев A.M. Правовые категории: методологические аспекты разработки системы категорий теории права: монография. репр. изд. М.: Норма: ИНФРА-М, 2021. 264 с.

Villar-Hernánde, Bartolo de Jesús, Pérez-Elizalde, S., Crossa J., Pérez-Rodríguez, P., Toledo, F.H. \& Burgueño, J. (2018) A bayesian decision theory approach for genomic selection. Genes, Genomes, Genetics. 8 (9), 3019-3037. https://doi.org/10.1534/g3.118.200430

Zholkov, C.U. (2017) Notion "information", in philosophy and theory of information. Philosophy and culture. (10), 55 - 66. https://doi.org/10.7256/2454-0757.2017.10.24183 (in Russian).

Жолков С.Ю. О понятии информации в философии и теории информации // Философия и культура. 2017. № 10. С. 55-66. https://doi.org/10.7256/2454-0757.2017.10.24183 


\section{About the author:}

Lyudmila N. Berg - Doctor of Legal Sciences, Associate Professor of the Department of Theory of State and Law; Ural State Law University, 21, Komsomolskaya str., Ekaterinburg, 620137, Russian Federation

ORCID ID: 0000-0001-8852-7971, SPIN-code: 8094-3503

e-mail: mila-berg@mail.ru

\section{Об авторе:}

Берг Людмила Николаевна - доктор юридических наук, доцент, профессор кафедры теории государства и права, Уральский государственный юридический университет; Российская Федерация, 620137, г. Екатеринбург, ул. Комсомольская, д. 21

ORCID ID: 0000-0001-8852-7971, SPIN-код: 8094-3503

e-mail: mila-berg@mail.ru 